Research/Technical Note

\title{
Development and Assessment of Composite Brake Pad Using Pulverized Cocoa Beans Shells Filler
}

\author{
Adeyemi Ibukun Olabisi. ${ }^{1,}$, , Ademoh Nuhu. Adam², Okwu Modestus Okechukwu ${ }^{1}$ \\ ${ }^{1}$ Department of Mechanical Engineering, Federal University of Petroleum Resources, Effurun, Warri, Nigeria \\ ${ }^{2}$ Department of Mechanical Engineering, Federal University of Technology, Minna, Nigeria
}

Email address:

adeyemi.olabisi@fupre.edu.ng (Adeyemi I. Olabisi.), adeibukola4christ2004@yahoo.com (Adeyemi I. Olabisi.)

${ }^{*}$ Corresponding author

\section{To cite this article:}

Adeyemi Ibukun Olabisi., Ademoh Nuhu. Adam, Okwu Modestus Okechukwu. Development and Assessment of Composite Brake Pad Using Pulverized Cocoa Beans Shells Filler. International Journal of Materials Science and Applications. Vol. 5, No. 2, 2016 , pp. 66-78. doi: 10.11648/j.ijmsa.20160502.16

Received: October 9, 2015; Accepted: October 21, 2015; Published: April 13, 2016

\begin{abstract}
Application of asbestos in friction material after a very long period is now discouraged due to its carcinogenic nature. There is need for alternative (human friendly) friction material. Hence the development of asbestos-free friction material from an agro-waste (cocoa beans shells - CBS) as filler element cum other additives was undertaken using powder metallurgy technique. The particulate size of the filler material considered was $300 \mu \mathrm{m}$ and epoxy resin was used as binder. The produced brake pad samples were analyzed by evaluating their mechanical, physical, and tribological properties. Based on the investigated properties of the developed brake pad, reducing the filler content increased the wear rate, tensile strength, compressive strength, while hardness, density, water absorption, oil absorption and thermal conductivity varied differently. Coefficient of friction increased with increase in the filler wt $\%$. The results showed that CBS particles could be effectively used as replacement for asbestos in automotive brake pad manufacture.
\end{abstract}

Keywords: Asbestos-Free, Composite Brake Pad, Cocoa Beans Shells (CBS), Mechanical and Tribological Properties

\section{Introduction}

Production and development of brake pad materials dates back to as far as 117 years ago. Brake pad materials usually are made with asbestos, metals and ceramics. It is now generally known that during application, asbestos releases hazardous gases which can cause damages to human health and this is not desirable, thus leading to searches for more human friendly materials. Asbestos is pronounced carcinogenic with associated diseases that include asbestosis, mesothelioma, lung cancer and other cancers [1]. This work aimed at obtaining a suitable friction material, taking cost, performance and environmental implication into consideration.

For all categories of vehicles that are equipped with brake discs, brake pads form vital components. They are steel backing plates with friction material fasten to the surface facing the brake disc [2]. Automobile brakes are of two types, namely, drum brakes and disc brakes. The brake shoes of drum brakes are situated inside a drum. On applying the brake, the brake shoe is forced outward and presses against the drum. One of the major differences between drum brakes and disc brakes is that drum brakes is usually enclosed while disc brakes are usually exposed to the environment [3] [4]. The brake pads generally consist of asbestos fibers embedded in polymeric matrix along with several other ingredients, but it is no longer acceptable due to its carcinogenic nature, thus new asbestos-free friction materials are being developed. Brake pads are tested to ascertain properties that make them suitable for the application. Properties to be determined include abrasion resistance, friction coefficient, hardness, tensile strength, specific gravity, compressive strength, oil absorption, water absorption, and thermal conductivity, disc temperature and stopping time [5]. Design and development of brake pad wear monitoring system for successful testing and validation was carried out by Sivarao et al. [6] who suggested that sensors at the manufacturing level be 
embedded into brake pads to give wear alerting sound.

In 1925, the British Belting and Asbestos (BBA) Limited became known as BBA Group that manufactured such very well-known friction material brand named as Mintex, Don, and Textar [7]. Owing to its effectiveness, chrysotile asbestos was used as a component in brake linings. However, studies such as a 1989 National Institutes of Health published report showed a rarely high proportion of brake mechanics were afflicted with pleural and peritoneal mesothelioma, both of which were linked to chrysotile and asbestos exposure. Public health authorities made a widespread recommendation against inhaling brake dust. Since then, chrysotile has been prohibited in many advanced countries, like Australia in late 2003. It has been progressively substituted in most brake linings and pads by fibers like synthetic aramids [8].

Blau [9] reported the additive effects of different kinds of non-asbestos materials on friction linings. As a result of these efforts, asbestos-free organic, semi-metallic and metallic friction lining materials are now increasingly being utilized. Non-asbestos organic (NAO) based friction materials are basically multi ingredient systems that usually contain over 10 ingredients intermixed to achieve expected combination of performance properties. The list of ingredients used for formulation of brake pad composites contains over 700 items. They are classified into four major categories, namely; binder fibers, friction modifiers and fillers based on the major function they perform apart from controlling friction and wear resistance. The central part of a system which binds the ingredients firmly so that they can perform the desired function in the friction materials is called binder. Friction modifiers are used to control the desired range of friction while fibers in amalgamation are included usually for strength. The two types of fillers available include; functional fillers for enhancing specific characteristic feature of composites such as resistance to fade, etc; and space/non-reactive fillers employed mainly to cut cost. Both modified and unmodified phenolic resins are always used as binders in friction materials because of low cost with good combination of mechanical properties such as high hardness, compressive strength, moderate thermal resistance, creep resistance, and very good wetting capability with most ingredients. These resins are sensitive to heat and humidity, and have poor shelf life as a result of in-situ polymerization which starts even at ambient temperature.

Most cars prior to late 1960s used drum brakes on all four wheels. The pads for these drum brakes were organic (i.e., composed of natural materials) and often consisted of resins and asbestos as well as a variety of other materials to help improve braking and wear. During that time down to early 1970s, automobile manufacturers started to incorporate disc brakes, especially for larger motor vehicles, because such brakes had better braking performance. In 1975, the Federal Motor Vehicle Safety Standard 105, which required more stringent braking requirements, helped expedite the transition to disc front - drum rear braking systems [9] [10]. Class A organic disc brake pads were the first adopted to make the switch from four wheel drum brake to disc front - drum rear systems. Class A organic brake pads were made from asbestos and were effective for low temperatures. As cars began to get smaller in late $1970 \mathrm{~s}$, it became more dificult to cool the brake pads. Class B organic pads performed better at higher temperatures, but had several problems including durability [11] [12] [13].

Consequently, the use of semi-metallic brake pads became more widely spread. Semi-metallic disc brake pads have lower wear rates and good braking properties at both low and high temperatures. Although the use of asbestos for brake pads has not been banned, but much of the brake pads industry is moving away from asbestos brake pads because of concerns regarding airborne particles in the factories and disposal of wastes containing asbestos. There are several patents for asbestos free organic friction materials [12].

Several researches have been carried out in the area of development of asbestos-free brake pads. The use of coconut shell, palm kernel shell (PKS) has been developed for asbestos free brake pads materials [2] [11] [12]. Researches globally today are focusing on ways of using either industrial or agricultural wastes as a source of raw materials in the industry. These wastes utilization will not only be economically advantageous, but may also result to foreign exchange earnings and environmental control. There is evolution of new materials and constituents currently used in automotive brake friction material after the phasing-out of asbestos, which had gained widespread acknowledgments as a carcinogen, although the introduction of the asbestos ban in some countries only came about in 1989. All forms of asbestos are carcinogenic. This ban was overruled in 1991 due to widespread complaints of the difficulty of finding asbestos replacements; existing uses of asbestos are still permitted, while new applications and uses (of asbestos) are banned [9].

Coconut shells based brake pad was produced by Bashar et al. [14]. The formulation included ground coconut shells (filler), epoxy resin (binder -matrix), iron chips (reinforcement), methyl ethyl ketone peroxide (catalyst), cobalt nephthanate (accelerator), iron and silica (abrasives), and brass (friction modifier). Sieve of $710 \mu \mathrm{m}$ aperture was used to sieve the pulverized filler. It was concluded that higher percentage of ground coconut powder gave lower breaking strength, hardness, compressive strength, and impact, and vice versa, thus high percentage of ground coconut powder induces brittleness, which is in line with the conclusion that the tensile and impact strength of treated and untreated palm kernel nut shells polymer composite decreases with increase in its filler content [15].

Yawas, et al. [16] produced brake pads from Periwinkle shells. In the work, periwinkle shell (asbestos-free) brake pad material was characterized and its morphology and properties were determined. The sun dried periwinkle shell was crushed accordingly, milled and sieved using a set of $+710,+500$, +355 , +250 , and $+125 \mu \mathrm{m}$ sieve aperture. The formulation included periwinkle shell powder, phenolic resin (phenol formaldehyde), engine oil (SEA 20/50), and water.

Aderiye Jide [17] carried out geological studies on kaolin clay group within the sedimentary mineral material zone of 
Ise-Orun-Emure local government areas of Ekiti State, Nigeria. The clay major characteristic properties were examined, beneficiated and processed for automotive friction lining material. It was discovered that kaolin clay group can be used because of its good heat resistance for friction lining material in automotive industries.

Idris et al. [18] investigated and produced brake pads using banana peels to replace asbestos with phenolic resin (phenol formaldehyde) as binder. The resin was varied from 5 to $30 \%$ wt in an interval of $5 \mathrm{wt} \%$. Studies were carried out on the physical, mechanical, wear and morphological properties of the brake pad. The results showed that compressive strength, hardness and specific gravity of the samples were increased with increased $w t \%$ of resin addition. The oil soak, water soak, wear rate and percentage charred decreased as resin $\mathrm{wt} \%$ increased. The samples containing $25 \mathrm{wt} \%$ in un-carbonized banana peels (UNCBp) and $30 \mathrm{wt} \%$ carbonized (CBp) gave better properties in all.

Egg Shells (EG) based eco-friendly (biodegradable) brake pad was developed and evaluated by Edokpia et al. [19]. Gum Arabic (GA) was used as binder. Both additives were investigated as possible replacement for asbestos and formaldehyde resin which are carcinogenic in nature and non-biodegradable. The brake pad formulation was produced by varying the GA from 3 to $18 \mathrm{wt} \%$. Tests carried out on samples included wear rate, thickness swelling in water and SAE oil, thermal resistance, specific gravity, compressive strength, hardness values and microstructure. Results showed that formulations containing 15 to $18 \mathrm{wt} \%$ of GA produced fair bonding. The sample with $18 \mathrm{wt} \%$ of GA in ES particles gave the best properties.

Ademoh and Adeyemi [20] developed maize husks (MH) based composite brake pad. In the work, filler particulate size of $300 \mu \mathrm{m}$ was used with epoxy resin as the binder. Based on the analytical tests conducted, it was concluded that reducing the filler content increased the hardness, wear rate, tensile strength, compressive strength and thermal conductivity of the developed brake pad, while density, coefficient of friction water absorption and oil absorption increased with increase in the filler $w \mathrm{t} \%$. The results showed that $\mathrm{MH}$ particles could be effectively used as replacement for asbestos and many bio-mass friction materials in automotive brake pad manufacture. Unlike asbestos based brake pad, the developed composite brake pad is eco-friendly without any known health implication.

In conjunction with the ongoing studies of the development of ecofriendly (asbestos-free) brake pads, an alternative production of composite brake pad was presented in this work, which used an agro-waste (cocoa beans shells CBS) as the base material. To a great degree, Cocoa tree (Theobroma cacao) is cultivated in Nigeria. In addition to the highly flavoured cocoa, the tree provides by-products like cocoa butter $(\mathrm{CB})$, cocoa pod husk $(\mathrm{CPH})$ and $\mathrm{CBS}$ among others. Cocoa bean shell is a potential tropical resource and its utilization in producing composite brake pad or friction lining among other uses will greatly reduce disposal problem facing cocoa processing factories in Nigeria. Cocoa Shell has
Nitrogen: Phosphorous: Potash of 3:1:3 [21]. The proximate composition of cocoa bean shells is summarized in Table 1.

Table 1. Proximate composition (\% dry matter) of cocoa bean shells.

\begin{tabular}{ll}
\hline Proximate & \% Composition \\
\hline Moisture & $4.90-12.00$ \\
Crude Protein & $13.20-20.10$ \\
Crude Fibre & $9.30-2.05$ \\
Ether extractable components & $1.90-22.00$ \\
Nitrogen-free extract & $40.20-52.50$ \\
Ash & $6.00-10.80$ \\
Source: Joseph [22] & \\
\hline
\end{tabular}

\section{Experimental Procedure}

\subsection{Materials/Equipment}

The materials selected for this work are: cocoa beans shells, silica sand, epoxy resin, calcium carbonate, anhydrous iron oxide, powdered graphite, talc (release agent), water, engine oil (SAE60), while laboratory equipment used included; sieve of aperture $300 \mu \mathrm{m}$ (BS $410-1$ ), spatula, stirrer, bowls, LCD series 2-digits and 3-digits electronic weigh balance, aluminum moulds, scrapper, hand gloves, universal testing machine (INSTRON 3369), micro hardness tester (LECO LM700AT), files, taber abrasion tester (TST) instrument (TSE-A016), measuring ruler, inclined plane, and modified Lee's disc apparatus. Table 2 presents the selected materials based on reasons. All laboratory and workshop equipment used were assessed at Engineering Materials Development Institute (EMDI) situated in Akure, Nigeria, and Federal University of Technology, Akure, Nigeria.

Table 2. Materials mix prepared for the brake pad production and reasons for choices.

\begin{tabular}{|c|c|c|}
\hline $\mathbf{S} / \mathbf{N}$ & Materials & Reason for selection \\
\hline 1. & $\begin{array}{l}\text { Matrix: Epoxy resin } \\
+ \text { Hardener } \\
\text { (Diethylenetriamine) }\end{array}$ & $\begin{array}{l}\text { Since it is not commonly used in brake pad } \\
\text { manufacture, its suitability as a binding } \\
\text { agent was to be explored. }\end{array}$ \\
\hline 2. & $\begin{array}{l}\text { Filler: Cocoa bean } \\
\text { shells }\end{array}$ & $\begin{array}{l}\text { They are wastes cheaply/readily available at } \\
\text { several dumping grounds in Nigeria, and } \\
\text { studies from literatures revealed that they } \\
\text { have properties which approve their } \\
\text { application in friction lining manufacture. } \\
\text { They are cheaper and easy to come-by. }\end{array}$ \\
\hline 3. & $\begin{array}{l}\text { Abrasives: Silica, } \\
\text { Iron Oxide }\end{array}$ & $\begin{array}{l}\text { They serve the purpose of increasing } \\
\text { friction and regulating the build-up of } \\
\text { friction film. }\end{array}$ \\
\hline 4. & $\begin{array}{l}\text { Reinforcement: } \\
\text { Calcium Carbonate } \\
\left(\mathrm{CaCO}_{3}\right)\end{array}$ & $\begin{array}{l}\text { Since barytes is costly, it is a low cost } \\
\text { alternative for influencing adhesion and } \\
\text { dispersion of polymer composite } \\
\text { fabrication [23]. }\end{array}$ \\
\hline 5. & $\begin{array}{l}\text { Friction Modifier: } \\
\text { Powdered graphite } \\
\text { ( } 75 \text { microns) }\end{array}$ & $\begin{array}{l}\text { It has no potential danger as it is used for } \\
\text { improving wet friction. }\end{array}$ \\
\hline
\end{tabular}

\subsection{Methods}

Powder metallurgy technique was used in producing test specimens [19] [20]. The base raw material (CBS) was collected separately, properly sun-dried, and cleaned to remove impurities. It was then crushed, ground into a fine 
powder and sieved (Figure 1) using a sieve of $300 \mu \mathrm{m}$ aperture.

A control test was first performed by pouring $250 \mathrm{~g}$ of epoxy resin into the moulds in order to determine the exact amount of mixture that would completely fill the mould cavities. Filler material (CBS) and matrix (epoxy resin and hardener) weights were varied while those of the abrasives (silica and Iron Oxide), friction modifier (pulverized graphite), and reinforcement (Calcium Carbonate $-\mathrm{CaCO}_{3}$ ) were kept constant. For each formulation, known amount (expressed in wt $\%$ (Table 3)) of filler, abrasives, friction modifier and reinforcement were measured into a container and thoroughly mixed for 15 minutes to obtain homogeneity. A known amount of the epoxy resin (polyepoxide) was poured into a separate container and a measured quantity of hardener (Diethylenetriamine) added to the portion. The epoxy resin and hardener were thoroughly stirred for 10 minutes to obtain uniform mixture. Then, the matrix mixture was poured onto the powdered material mixture and stirred further to obtain a paste-like homogenous mixture. The formed paste was poured into the mould cavities and allowed to cure. Talc was initially applied to the surface of mould cavity for easy removal of specimens after curing. Resistance to flow of paste decreased as percentage by weight of matrix (binder) increased. The curing time was observed to range from 80 minutes to 120 minutes depending on the ratios of epoxy resin to hardener in the mixture. For instance, 1:2 hardener to epoxy resin mixture requires 80 minutes curing time, while 1:3 hardener to epoxy resin mixture requires curing time of 120 minutes. During production, it was observed that changing the matrix mixing ratio from 1:2 to $1: 3$ reduced casting porosity, but increased curing time. The specific epoxy resin to hardener mixing ratio used for this work is $1: 3$. The same process was repeated to produce other samples of different compositions.

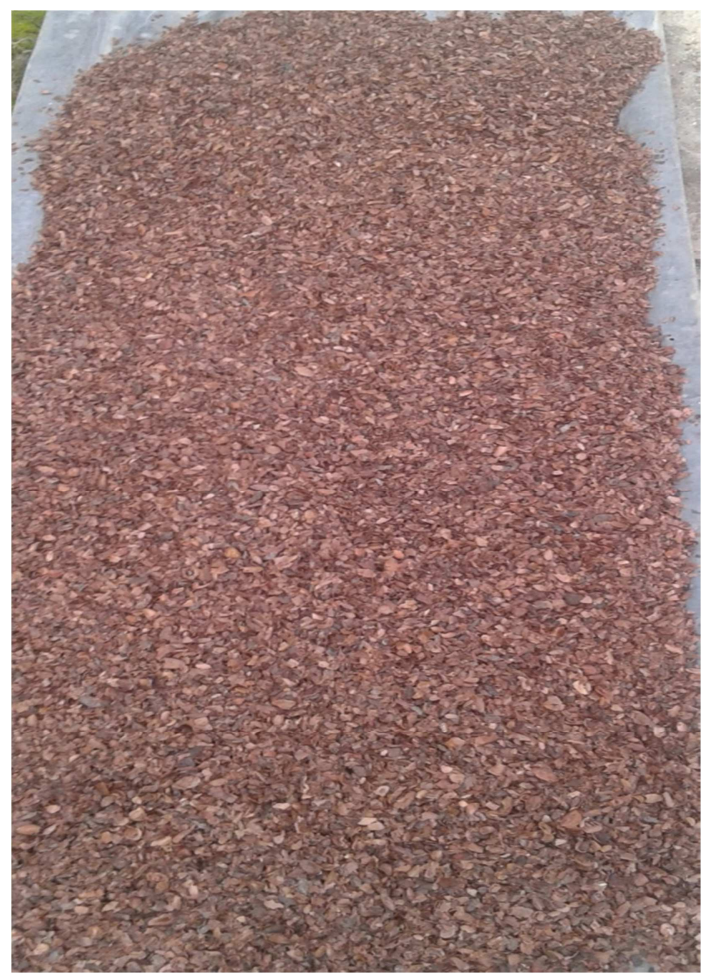

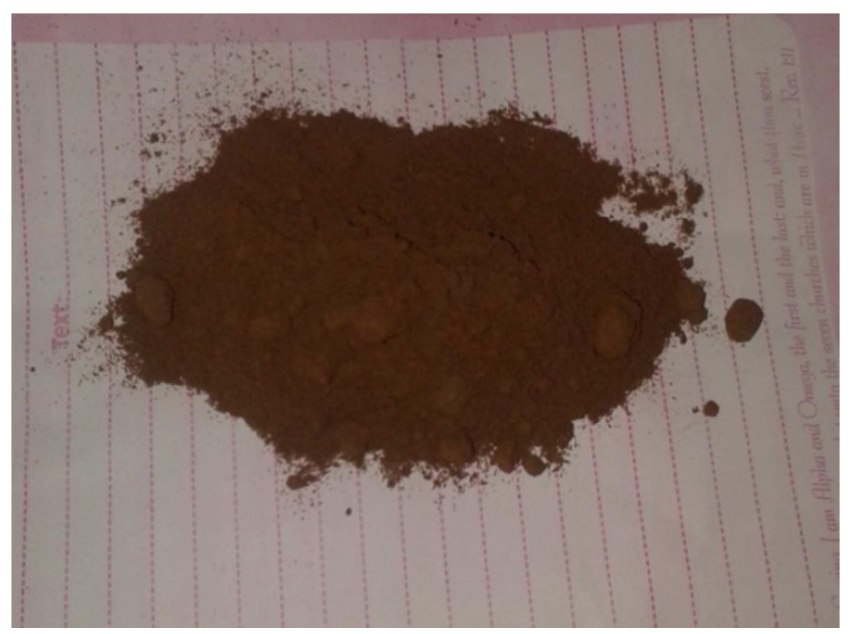

Figure 1. Photographs of raw and powdered $(300 \mu \mathrm{m})$ cocoa beans shells.

Table 3. wt\% Composition of specimen formulation.

\begin{tabular}{|c|c|c|c|c|}
\hline $\mathbf{S} / \mathbf{N}$ & MATERIAL & $\begin{array}{l}\text { Comp. } 1 \\
(w t \%)\end{array}$ & $\begin{array}{l}\text { Comp. } 2 \\
(\mathrm{wt} \%)\end{array}$ & $\begin{array}{l}\text { Comp. } 3 \\
(w t \%)\end{array}$ \\
\hline 1. & Epoxy resin + Hardener & 50.0 & 55.0 & 60.0 \\
\hline 2. & $\mathrm{CaCO}_{3}$ & 4.0 & 4.0 & 4.0 \\
\hline 3. & $\begin{array}{l}\text { Cocoa beans shells } \\
\text { powder }\end{array}$ & 31.0 & 26.0 & 21.0 \\
\hline \multirow{2}{*}{4.} & Silica & 7.0 & 7.0 & 7.0 \\
\hline & Iron Oxide & 3.0 & 3.0 & 3.0 \\
\hline \multirow[t]{2}{*}{5.} & Powdered Graphite & 5.0 & 5.0 & 5.0 \\
\hline & Total & 100.0 & 100.0 & 100.0 \\
\hline
\end{tabular}

It should be noted that the reddish brown colour of all the samples is due to the iron oxide included in the formulation. After production of samples, they were left in an aerated environment for 21 days in order to allow them attain full strength before carrying out analytical tests on them. But from literatures, the allowed period to attain full strength before carrying out mechanical tests is 7days [24] [25]. To ascertain the suitability of a material for friction application, tests to be carried out included density test, water and oil absorption tests, wear (abrasion) resistance test, coefficient of friction test, thermal conductivity test, hardness test, tensile strength test, and compressive strength test [7] [12] [19] [20] [26].

\subsubsection{Density Test}

Density test was conducted on the experimental brake pad by using Archimedes' principle. This principle was useful for determining the volume and therefore the density of an irregularly shaped object by measuring its mass in air and its effective mass when submerged in water $\left(\right.$ density $\left.=1 \mathrm{~g} / \mathrm{cm}^{3}\right)$. The density is expressed in equation 1

$$
\text { Density }=(\text { Weight in air }) /(\text { Volume of water displaced })
$$

\subsubsection{Water and Oil Absorption Tests}

Water and oil absorption tests were conducted as shown in Figure 2 and 3 respectively. The initial weight of each specimen was taken and recorded as $\mathrm{W}_{0}$ before soaking into water and engine oil separately. The oil used was automotive engine oil of rating SAE60. The test took 48 hours. At an interval of 24 hours, specimens were brought out of water and oil, thoroughly cleaned to drain water and oil on their surfaces 
and reweighed to determine the new weights that were recorded as $\mathrm{W}_{1}$ and used later to determine the absorption rates. The absorptions were then computed using equation (2) [19] [20].

$$
\text { Absorption }(\%)=\left(\left(W_{1}-W_{0}\right) / W_{0}\right) \times 100
$$

Where: $\mathrm{W}_{0}$ is the weight before immersion and $\mathrm{W}_{1}$ is the weight after immersion.

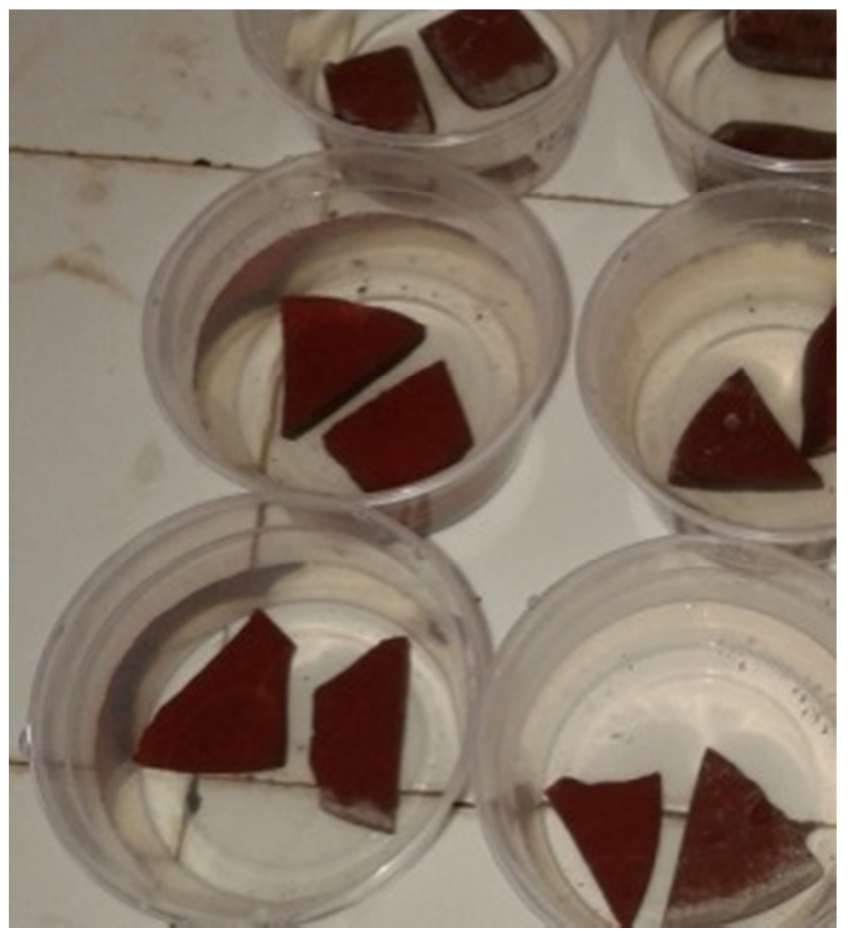

Figure 2. Water absorption test.

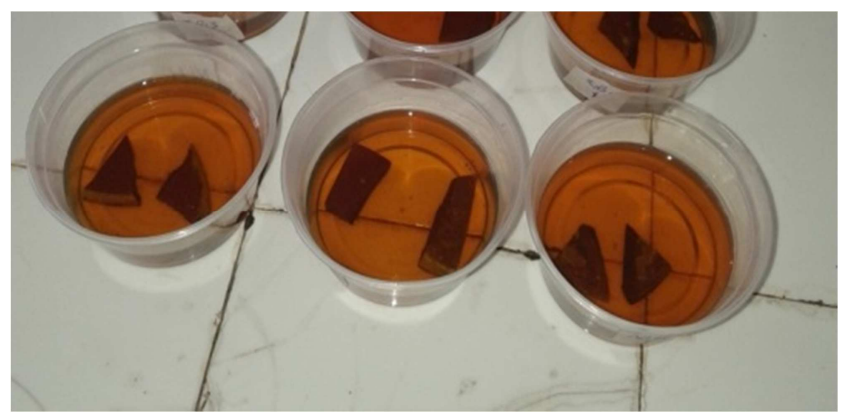

Figure 3. Oil (SAE60) absorption test.

\subsubsection{Abrasion Resistance Test}

Abrasion resistance test was carried out with the aid of a taber abrasion tester (TST instrument - model TSE-A016). Each test specimen (Figure 4) measured $110 \mathrm{~mm}$ diameter and $6 \mathrm{~mm}$ thickness. The specimens were weighed and recorded as $\mathrm{W}_{0}$ before the test using an FA2204B 4-didit electronic weigh balance. The test specimen was fixed to the rotary disc (100mm dia.) of the machine with the aid of a nut at its centre. Two emery wheels at the upper arm of the machine were allowed to have direct contact with the specimen fastened to the rotary disc. The machine was turned on (powered at 220V) and the disc rotated at a constant speed of $85 \mathrm{rev} / \mathrm{mins}$ for a pre-set time of 1000 seconds. As the disc rotated, the two emery wheels in direct contact with the specimen also rotated at a relative speed to the disc and caused the specimen to wear. After the pre-set time, the machine was turned off automatically. The specimen was thoroughly cleaned and the final weight was measured and recorded as $\mathrm{W}_{1}$. The weight loss of the specimen was determined by finding the difference between the final and initial weights. Thus, the wear rate was determined using equation (3) [19] [20].

Wear Rate $=\left(W_{0}-W_{1}\right) / s=\Delta W / S=\Delta W /(2 \pi N D \times t)$

Where: $\mathrm{W}_{0}$ is the initial weight, $\mathrm{W}_{1}$ is the final weight, $\Delta \mathrm{W}$ is the weight loss, $\mathrm{S}$ is the sliding distance, $\mathrm{D}(0.1 \mathrm{~m})$ is the disc diameter, $\mathrm{N}$ ( $85 \mathrm{rev} / \mathrm{mins})$ is the radial speed $(\mathrm{rpm})$, and $\mathrm{t}$ $(1,000$ secs $)$ is the time taken to expose the specimen to wear.
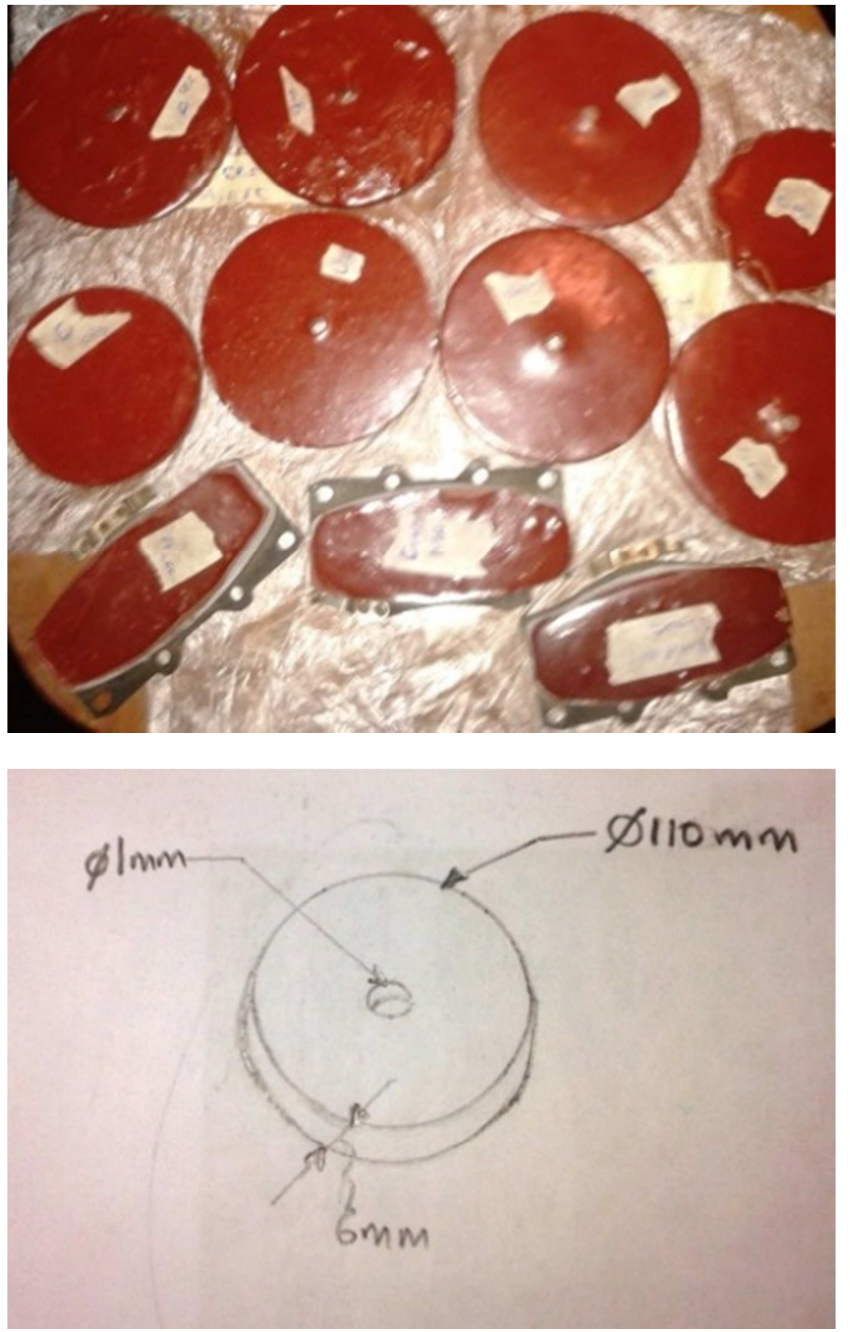

Figure 4. Photograph and schematic diagram of abrasion test specimens.

\subsubsection{Friction Coefficient Test}

The coefficient of friction of each test specimen was determined with the aid of an inclined plane (model number: FUTA/PHY/IP/025) and a $90^{\circ}$ wedge as illustrated in Figure 5. Each specimen was placed on the inclined plane with the wedge in place. The wedge position was varied to increase inclination angle until the test sample was just about to slide 
down the plane. The resulting coefficient of static friction $(\mu)$ was calculated from equation (4) [20] [27].

$$
\mu=\tan \theta=(\text { opp. }) /(\text { adj. })
$$

Where: opp. means opposite and adj. means adjacent.

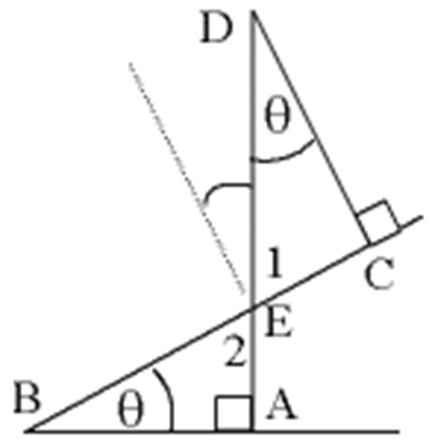

Figure 5. Analysis of coefficient of static friction.

\subsubsection{Thermal Conductivity Test}

The thermal conductivity test on specimen was carried out with the aid of a Modified Lee's disc apparatus as schematically shown below in Figure 6 [28].

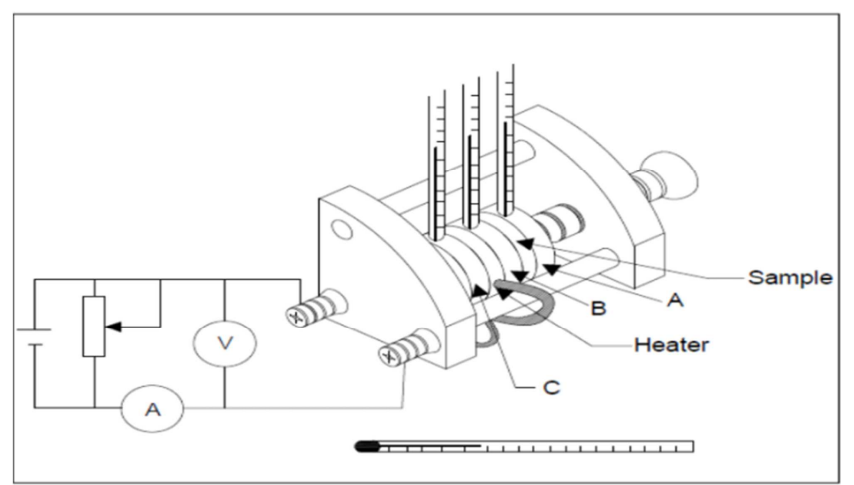

Figure 6. Schematic diagram of a typical thermal conductivity (Lee's disc) apparatus.

[20] The setup consists of a power source, a rheostat, an ammeter and voltmeter, four thermometers that measure temperatures of disc $\mathrm{A}\left(\mathrm{T}_{\mathrm{A}}\right)$, disc $\mathrm{B}\left(\mathrm{T}_{\mathrm{B}}\right)$, disc $\mathrm{C}\left(\mathrm{T}_{\mathrm{C}}\right)$ and surrounding (ambient $-\mathrm{T}_{\text {Amb. }}$ ) respectively. The experiment was performed in an enclosed environment in order to minimize heat loss to surrounding. The discs were made up of brass and each having diameter of $4.14 \mathrm{~cm}$. Each disc had a hole drilled into it via the edge to a certain depth to accommodate the thermometer. Inside each hole was poured glycerine for proper contact. Between disc B and $\mathrm{C}$ was the heater that kept disc $\mathrm{B}$ and $\mathrm{C}$ in thermal equilibrium on heating. The test specimen measured as $\varnothing 41 \mathrm{~mm}, 5 \mathrm{~mm}$ thickness for conductivity test was placed between disc B and A, all in contact with each other. To start heating up (for rising temperature readings), the rheostat was set to adjust the voltage to a maximum value of $6 \mathrm{~V}$. After 5 minutes interval, temperature rise readings were taken until equilibrium was attained and this was repeated six times consecutively. Thereafter, the rheostat was also reset to reduce both the voltage and current in order to make the temperature fall. Falling temperature readings were also taken after 5 minutes interval until equilibrium was attained. Results of the thermal conductivity, $\lambda(\mathrm{W} / \mathrm{mk})$ of each sample of thickness, $\mathrm{t}(\mathrm{mm})$ and radius, $\mathrm{r}(\mathrm{mm})$ were presented in equations (5):

$$
\lambda=e d /\left(2 \pi r^{2}\left(T_{B}-T_{A}\right)\right)\left[a_{S}\left(T_{A}+T_{B}\right) / 2+2 a_{A} T_{A}\right.
$$

Where e is given by

$$
e=V I /\left[a_{A} T_{A}+a_{S}\left(T_{A}+T_{B}\right) / 2+a_{A} T_{B}+a_{C} T\right]
$$

and

$$
\begin{aligned}
& a_{A}=a_{c}=\pi r^{2}+2 \pi r l_{d} \\
& a_{B}=2 \pi r l_{d} \\
& a_{s}=2 \pi r l_{S}
\end{aligned}
$$

Where $1_{d}$ and $1_{S}$ were the disc thickness and sample thickness respectively, while $a_{A}, a_{B}, a_{C}$, and $a_{S}$ were the exposed surface areas of discs $\mathrm{A}, \mathrm{B}, \mathrm{C}$ and the specimen respectively. $T_{A}, T_{B}$ and $T_{C}$ were the temperatures of the discs $\mathrm{A}, \mathrm{B}$ and $\mathrm{C}$ above ambient (i.e. the thermal equilibrium temperature of disc minus ambient temperature). $\mathrm{V}$ and I are the potential difference across the heater and current which flowed through it respectively. To fully analyze the thermal characteristics of samples within the temperature range, a MATLAB programme was developed to compute the thermal conductivity at different heating time intervals. Appropriately sized test specimens with dimensions are shown in Figure 7.
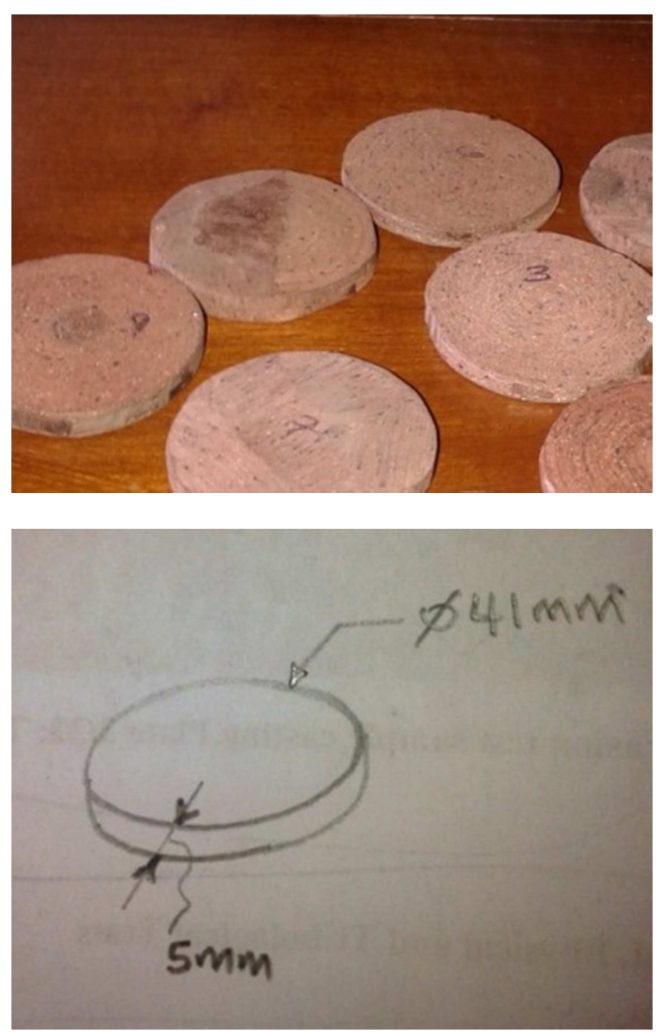

Figure 7. Photograph and schematic diagram of thermal conductivity test specimens. 


\subsubsection{Hardness Test}

The hardness test was performed with the aid of a digital Micro Hardness Tester of $490.3 \mu \mathrm{N}$ load sensitivity (model: LECO LM700AT). The specimen was indented for 10 seconds (dwell time), after which corresponding Vicker's hardness numbers were automatically read from the digital counter [20].

\subsubsection{Tensile Strength Test}
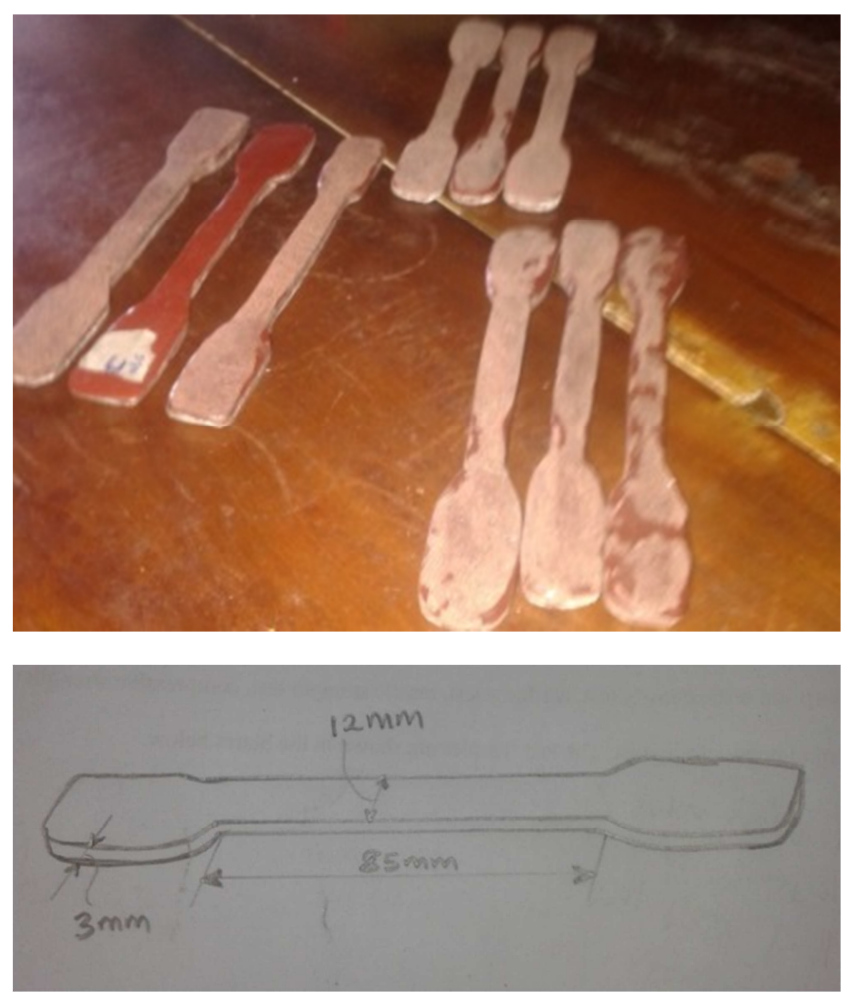

Figure 8. Photograph and schematic diagram of tensile strength test specimens.

The tensile test on the specimen was carried out using an electronic universal testing machine (Model: INSTRON 3369). The specimen average gauge length, width and thickness measured $85 \mathrm{~mm}, 11 \mathrm{~mm}$ and $6 \mathrm{~mm}$ respectively (Figure 8). In carrying out the test, one end of the specimen was gripped in the jaws attached to the adjustable crosshead and then after lifting this crosshead to the appropriate height, the other end of the specimen was fixed in jaws in the top crosshead. Then tensile load was hydraulically applied to the specimen by pressing the start bottom provided in the control unit. The input and output display unit in the control unit indicated magnitude of applied load. The load was gradually increased until specimen broke off and corresponding extension was noted and recorded. The automatically generated test data were shown on the display unit [20].

\subsubsection{Compressive Strength Test}

Compression test on the specimen was performed with the aid of an electronic universal testing machine (Model: INSTRON 3369). Test samples were shaped and averagely dimensioned as $40 \mathrm{~mm} \times 12 \mathrm{~mm} \times 6 \mathrm{~mm}$ (Figure 9). The compression was used as the reverse of tensile test as a standard method of testing brittle materials like cast iron, concrete, stones, bricks, ceramics, mortals, and other materials because the compressive strength of materials when carefully done also gives direct information on the tensile strength [29]. The compression test was performed by placing the specimen between the compression plates provided in the adjustable cross head and bottom crosshead. After specimen was properly positioned and gripped firmly between the compression plates, load was applied and the compressive strain was read from the output display unit. The load was gradually applied on the specimen and the corresponding strain was recorded at regular intervals [20].

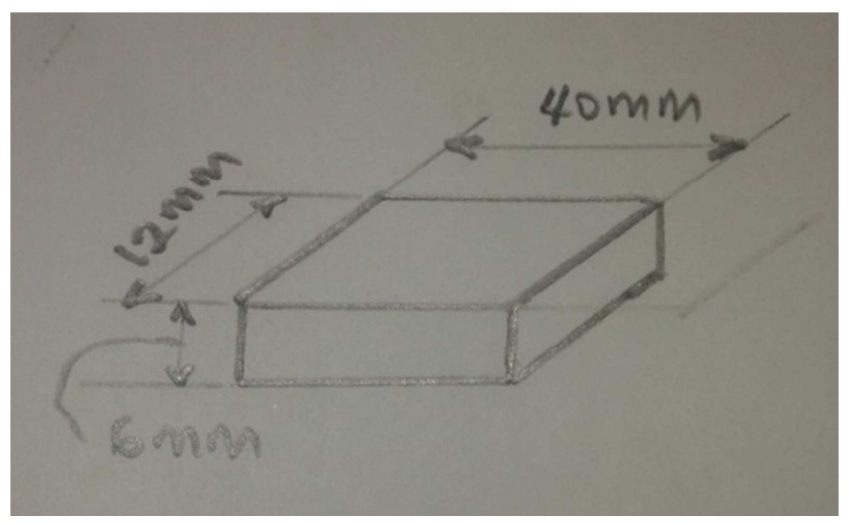

Figure 9. Schematic diagram of compression test specimen.

\section{Results and Discussion}

\subsection{Density Assessment}

Table 4 presents results of density of the composite brake pad considered and it is graphically analyzed as shown in Figure 10.

Table 4. Density of the composite brake pad.

\begin{tabular}{|c|c|c|c|c|c|c|}
\hline Test № & Materials/Composition & $\begin{array}{l}\text { Weight in air, } \\
\mathbf{W}_{\text {air }}(\mathrm{g})\end{array}$ & $\begin{array}{l}\text { Volume of water } \\
\text { displaced, } V\left(\mathrm{~cm}^{3}\right)\end{array}$ & $\begin{array}{l}\text { Average Weight in } \\
\text { air, } W_{\text {air(avg.) }}(\mathrm{g})\end{array}$ & $\begin{array}{l}\text { Average Vol. of water } \\
\text { displaced, } V_{\text {avg. }}\left(\mathrm{cm}^{3}\right)\end{array}$ & $\begin{array}{l}\text { Average Density, } \\
\rho_{\text {avg. }}\left(\mathrm{g} / \mathrm{cm}^{3}\right)\end{array}$ \\
\hline \multirow{2}{*}{$\begin{array}{l}1 . \\
2 .\end{array}$} & \multirow{2}{*}{ Sample Composition 1} & 7.230 & 5.620 & & & \\
\hline & & 7.310 & 5.720 & 7.270 & 5.670 & 1.282 \\
\hline \multirow{2}{*}{$\begin{array}{l}1 . \\
2 .\end{array}$} & \multirow{2}{*}{ Sample Composition 2} & 6.230 & 4.630 & & & \\
\hline & & 5.710 & 4.090 & 5.970 & 4.360 & 1.369 \\
\hline \multirow{2}{*}{$\begin{array}{l}1 . \\
2 .\end{array}$} & \multirow{2}{*}{ Sample Composition 3} & 5.110 & 5.020 & & & \\
\hline & & 5.830 & 5.811 & 5.470 & 5.416 & 1.010 \\
\hline
\end{tabular}




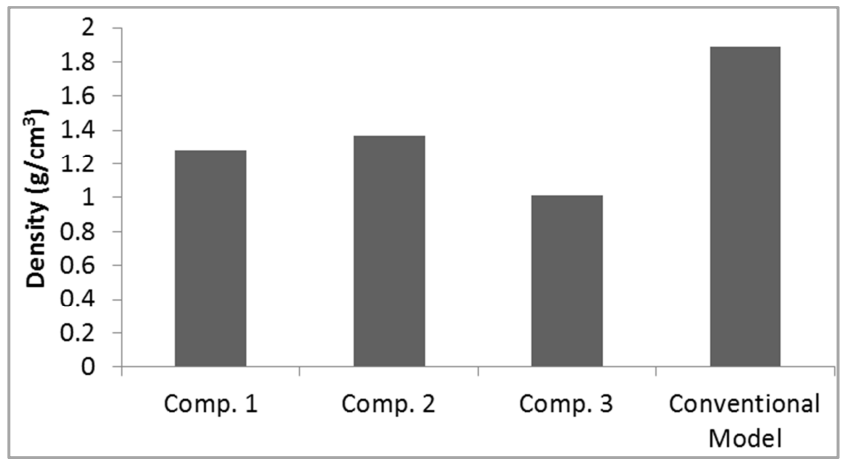

Figure 10. Density analyses of samples.

Figure 10 showed that densities of the samples increased up to a point and declined thereafter as the filler $w t \%$ in the formulation decreased. Increase in specific gravity was attributed to increased packing of filler particles forming more homogeneity in the entire phase of the brake pad composite body [19] [20]. This showed that a particular composition would give the most acceptable density, and this could only be achieved through optimization. However, weights of the investigated composite specimens compared favourably over the conventional model. They are lighter in weight, thus conform to standard [26]. The density of conventional brake pad is $1.890 \mathrm{~g} / \mathrm{cm}^{3}$. Density of each composite specimen varied from that of the conventional brake pad according to composition (1, 2 and 3 ), by $33.17 \%, 27.57 \%$ and $45.56 \%$ respectively. Lower density denotes better quality than the conventional brake pad in accordance with the standard recommended for brake pad application [19] [20].

\subsection{Water and Oil Absorption}

Table 5 presents water and oil absorption of specimens. Water and oil absorption of specimens was compared with that of the conventional brake pad as illustrated in Figure 11 which shows that water and oil absorbent properties of specimens varied non-uniformly as percentage weight of fillers decreased from $31 \%$ wt to $21 \%$ wt in the formulation. Lower water and oil absorption capacity could be attributed to increase in interfacial bonding between the binder and filler particles which lead to decrease in porosity level [19] [20]. The results compared favourably with the conventional model. Water and oil absorption of conventional brake pad is $0.9 \%$ and $0.3 \%$ respectively [18] [20]. Water and oil absorptions of composite specimen labeled as composition 3 (21\%wt of filler) are below that of the conventional brake pad. Hence they are better than the conventional model in terms of water and oil absorption. Water absorption deviation of each composite specimen from that of the conventional brake pad is 0.063 (comp.1), -0.146 (comp. 2) and 0.288 (comp. 3), while that of oil absorption is $0.267,0.444$ and -0.025 accordingly.

Table 5. Water and Oil absorption (\%) of the specimen brake pads.

\begin{tabular}{|c|c|c|c|c|c|c|}
\hline \multirow[b]{2}{*}{ Material/Composition } & \multicolumn{3}{|l|}{ Water } & \multicolumn{3}{|l|}{ Oil } \\
\hline & $\begin{array}{l}\text { Average Initial } \\
{\text { Weight, } \mathbf{W}_{\text {o(avg.) }} \text { (g) }}\end{array}$ & $\begin{array}{l}\text { Average Weight } \\
\text { gain, } \Delta \mathbf{W}_{\text {avg. }}(\mathrm{g})\end{array}$ & Absorption (\%) & 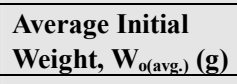 & $\begin{array}{l}\text { Average Weight } \\
\text { gain, } \Delta \mathbf{W}_{\text {avg. }}(\mathrm{g})\end{array}$ & Absorption (\%) \\
\hline Sample Composition 1 & 7.270 & 0.070 & 0.963 & 5.290 & 0.030 & 0.567 \\
\hline Sample Composition 2 & 5.970 & 0.045 & 0.754 & 4.03 & 0.030 & 0.744 \\
\hline Sample Composition 3 & 5.470 & 0.065 & 1.188 & 3.630 & 0.010 & 0.275 \\
\hline
\end{tabular}

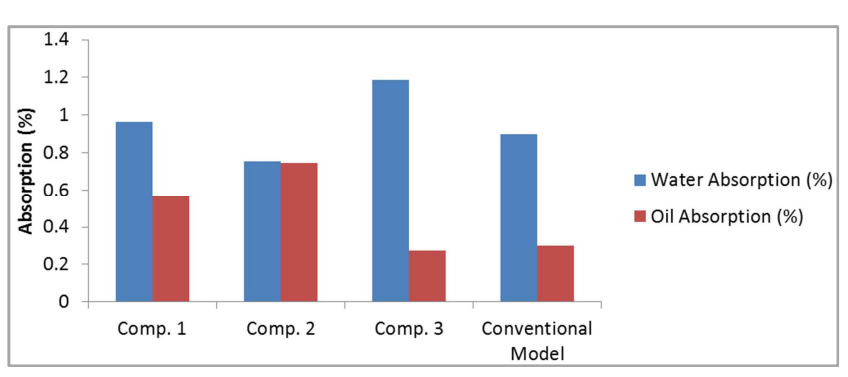

Figure 11. Water and oil absorption analysis of the samples.

The negative variance shows that water and oil absorption of the composite is below that of the conventional model, thus they are better than the conventional model in terms of water and oil absorption. Sample labeled as composition 2 (55wt\% of binder) has the least water absorption, thus it also compared better than that of palm kernel shell based pad [11], bagasse based pad [2] and egg shells based pad [19] with variance of $-4.276,-2.726$ and -2.456 respectively, while sample labeled as composition $3(60 \mathrm{wt} \%$ of matrix) has the least oil absorption and compared better than that of palm kernel shells based pad, bagasse based pad, egg shells based pad and periwinkle shells based pad [16] with variance of -0.165 , $-0.835,0.875$ and 0.095 respectively. By implication, composite pads that have better water/oil absorption than the conventional model and other existing ones can exhibit better resistance to water or oil on exposure during application.

\subsection{Wear (Abrasion) Resistance Assessment}

Wear rates of composite specimens with different composition are as shown in Table 6.

Table 6. Wear Rate of specimen brake pads.

\begin{tabular}{|c|c|c|c|c|c|}
\hline $\begin{array}{l}\text { Composition/ } \\
\text { Material }\end{array}$ & $\mathbf{W}_{\mathrm{o}}(\mathrm{g})$ & $\mathrm{W}_{1}(\mathrm{~g})$ & $\begin{array}{l}\text { Time } \\
\text { (sec) }\end{array}$ & $\begin{array}{l}\text { Average } \\
\Delta \mathbf{W}(\mathbf{g})\end{array}$ & $\begin{array}{l}\text { Wear Rate } \\
\times 10^{-6}(\mathrm{~g} / \mathrm{m})\end{array}$ \\
\hline $\begin{array}{l}\text { Sample } \\
\text { Composition } 1\end{array}$ & 146.429 & 146.425 & 1000 & 0.004 & 0.715 \\
\hline $\begin{array}{l}\text { Sample } \\
\text { Composition } 2\end{array}$ & 99.245 & 99.237 & 1000 & 0.008 & 1.430 \\
\hline $\begin{array}{l}\text { Sample } \\
\text { Composition } 3\end{array}$ & 117.665 & 117.643 & 1000 & 0.022 & 3.934 \\
\hline
\end{tabular}


Figure 12 below shows that wear rate of specimens increased as the epoxy resin content increased from $50 \%$ wt to $60 \%$ wt. It may be said that higher content of CBS than epoxy resin will lower interfacial bonding which may result in higher wear. For all the samples, the wear rates compared favourably over the conventional model and others produced from similar researches. Wear rate of conventional brake pad is $3.80 \times$ $10^{-6} \mathrm{~g} / \mathrm{m}[19][20]$.

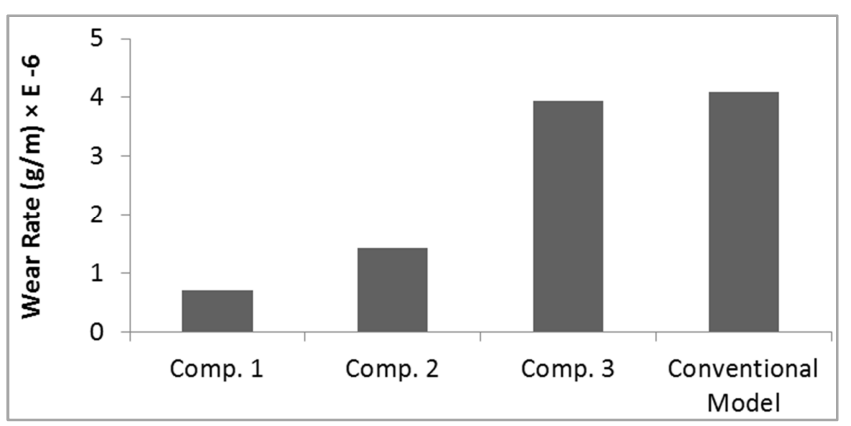

Figure 12. Wear rate analysis of specimens.

Wear rates of composite specimens labeled as composition 1 (31\%wt of filler) and composition $2(26 \%$ wt of filler) are below that of the conventional brake pad with variances -3.085 and -2.370 respectively. The negative variance shows that wear rate of the composite is below that of the one being compared with (conventional model), thus they are better in terms of abrasion resistance. Specimen brake pad labeled as composition 1 ( $50 \%$ wt of binder) has the least value, and this made it much better than that of conventional brake pad [20, 30], palm kernel shell (PKS) based pad [11], bagasse (BG) based pad [2] and egg shells (EG) based pad [19] with variance of $-3.085,-3.685,-3.485$ and -3.285 respectively.

\subsection{Friction Coefficient Assessment}

Table 7. Coefficient of friction ( $\mu$ ) of specimens with different composition.

\begin{tabular}{|c|c|c|c|c|c|}
\hline $\begin{array}{l}\text { Composition/ } \\
\text { Material }\end{array}$ & $\begin{array}{l}\text { Adj. } \\
(\mathrm{cm})\end{array}$ & $\begin{array}{l}\text { Opp. } \\
\text { (cm) }\end{array}$ & $\begin{array}{l}\text { Angle, } \theta \\
\left({ }^{\circ}\right)\end{array}$ & $\begin{array}{l}\text { Average } \\
\theta\left({ }^{\circ}\right)\end{array}$ & $\begin{array}{l}\text { Average friction } \\
\text { coefficient }(\mu)\end{array}$ \\
\hline $\begin{array}{l}\text { Sample } \\
\text { Composition } 1\end{array}$ & 30.90 & 10.7 & 19.10 & 19.10 & 0.35 \\
\hline $\begin{array}{l}\text { Sample } \\
\text { Composition } 2\end{array}$ & 31.70 & 10.7 & 18.65 & 18.65 & 0.34 \\
\hline $\begin{array}{l}\text { Sample } \\
\text { Composition } 3\end{array}$ & 34.00 & 10.7 & 17.50 & 17.50 & 0.32 \\
\hline
\end{tabular}

Table 7 presents the coefficient of friction of specimens. Coefficient of friction, $\mu=\tan \theta$. From Table 7 as graphically analyzed in Figure 13, it could be inferred that for each specimen, the coefficient of friction decreased as the $\mathrm{wt} \%$ of the filler decreased in the composition. The results compare favourably with the standard value [26]. The coefficient of friction for conventional brake pad ranges from 0.3 to 0.4 [18]. Mean friction coefficient of conventional brake pad is 0.35 . Friction coefficients of composite specimens labeled as composition 2 (26wt $\%$ of filler) and composition 3 (21wt $\%$ of filler) are below the mean value of that of the conventional brake pad with variance of -0.01 and -0.03 respectively. Whereas, sample labeled as composition 1 ( $31 \mathrm{wt} \%$ of filler) has the same value of friction coefficient with the conventional model. The negative difference shows that friction coefficient of the specimen is below that of the conventional model. However, the values are still within standard range.

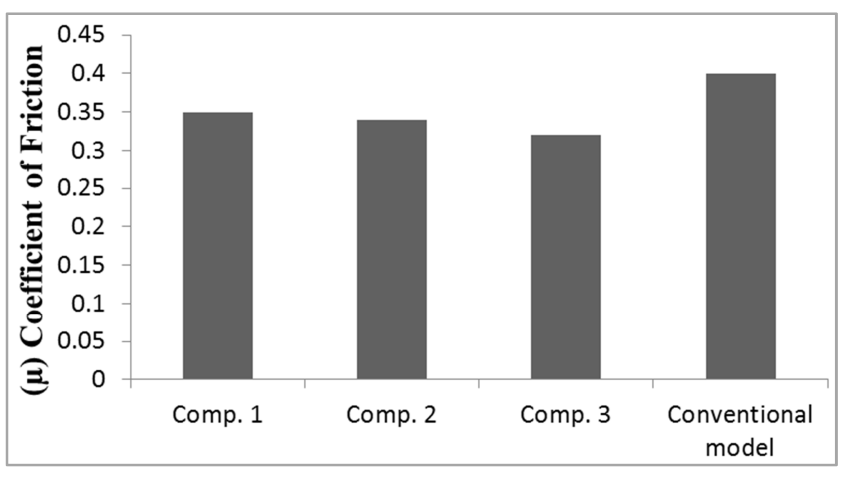

Figure 13. Coefficient of friction $(\mu)$ of different specimen composition.

Mean friction coefficient of conventional brake pad is 0.35 . Friction coefficients of composite specimens labeled as composition 2 (26wt $\%$ of filler) and composition 3 (21wt $\%$ of filler) are below the mean value of that of the conventional brake pad with variance of -0.01 and -0.03 respectively. Whereas, sample labeled as composition 1 ( $31 \mathrm{wt} \%$ of filler) has the same value of friction coefficient with the conventional model. The negative difference shows that friction coefficient of the specimen is below that of the conventional model. However, the values are still within standard range.

\subsection{Thermal Conductivity Assessment}

Table 8. Thermal conductivity of specimen brake pad.

\begin{tabular}{llll}
\hline Materials / Composition & $\begin{array}{l}\text { Thickness } \\
(\mathbf{m m})\end{array}$ & $\begin{array}{l}\text { Diameter } \\
(\mathbf{m m})\end{array}$ & $\begin{array}{l}\text { Thermal } \\
\text { Conductivity, } \boldsymbol{\lambda} \\
\text { (W/mk) }\end{array}$ \\
\hline Sample Composition 1 & 6.35 & 38.80 & 0.2746 \\
Sample Composition 2 & 5.30 & 49.00 & 0.3380 \\
Sample Composition 3 & 5.70 & 39.80 & 0.2387 \\
\hline
\end{tabular}

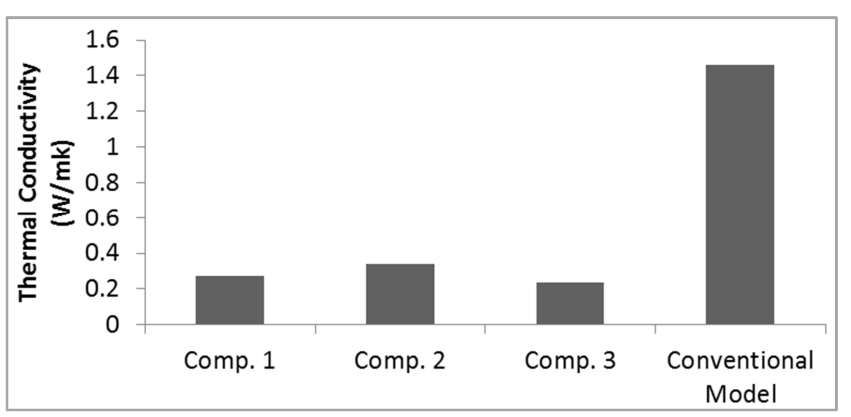

Figure 14. Comparative analysis of thermal conductivity of the specimen brake pad.

From Table 8 which presents the thermal conductivity of specimen brake pad, it was discovered that thermal conductivity increased as the $\mathrm{wt} \%$ of filler decreased from 
$31 \mathrm{wt} \%$ to $26 \mathrm{wt} \%$ and later decreased as filler content decreased from $26 \mathrm{wt} \%$ to $21 \mathrm{wt} \%$ in the formulation. Increased thermal conductivity may be attributed to lower interfacial bonding between filler particles and matrix. Thermal conductivity of each composite pad was compared with that of the conventional brake pad as shown in Figure 14. Thermal conductivity of conventional brake pad is $0.539 \mathrm{~W} / \mathrm{mk}$ [20] [30].

As shown in Figure 14 above, thermal conductivity of each specimen is far below that of the conventional brake pad $(0.539 \mathrm{~W} / \mathrm{mK})$. This infers that the specimens have higher heat resistance characteristics than the conventional model. Low thermal conductivity increases tendency of raising pad temperature as increased thermal resistance builds up temperature at the contacting surfaces. For most agro-waste based pads developed as obtained from literature, no information is available on thermal conductivity except palm kernel shell based brake pad $(1.460 \mathrm{~W} / \mathrm{mK})$ developed by Dagwa and Ibhadode [11]. Thermal conductivity of each specimen (comp. 1, 2 and 3) varied from that of the conventional brake pad by $43.95 \%, 37.24 \%$ and $55.65 \%$ respectively.

\subsection{Hardness Assessment}

Table 9 shows hardness values of specimen brake pads.

Table 9. Hardness value of specimen brake pads.

\begin{tabular}{|c|c|c|c|c|}
\hline Materials/Composition & $\mathbf{S} / \mathbf{N}$ & $\begin{array}{l}\text { Hardness } \\
\text { Number } \\
\text { (HV) }\end{array}$ & $\begin{array}{l}\text { Average } \\
\text { Hardness } \\
\text { Number } \\
\text { (HV) } \\
\end{array}$ & $\begin{array}{l}\text { Average } \\
\text { Hardness } \\
\text { Value } \\
\text { (MPa) } \\
\end{array}$ \\
\hline \multirow{3}{*}{ Sample Composition 1} & 1. & 11.50 & \multirow{3}{*}{11.13} & \multirow{3}{*}{109.15} \\
\hline & 2. & 10.90 & & \\
\hline & 3. & 11.00 & & \\
\hline \multirow{3}{*}{ Sample Composition 2} & 1. & 10.40 & \multirow{3}{*}{10.67} & \multirow{3}{*}{104.64} \\
\hline & 2. & 11.10 & & \\
\hline & 3. & 10.5 & & \\
\hline \multirow{3}{*}{ Sample Composition 3} & 1. & 12.20 & \multirow{3}{*}{12.27} & \multirow{3}{*}{120.33} \\
\hline & 2. & 11.80 & & \\
\hline & 3. & 12.80 & & \\
\hline
\end{tabular}

Specimen hardness is compared with that of the conventional model as illustrated in Figure 15.

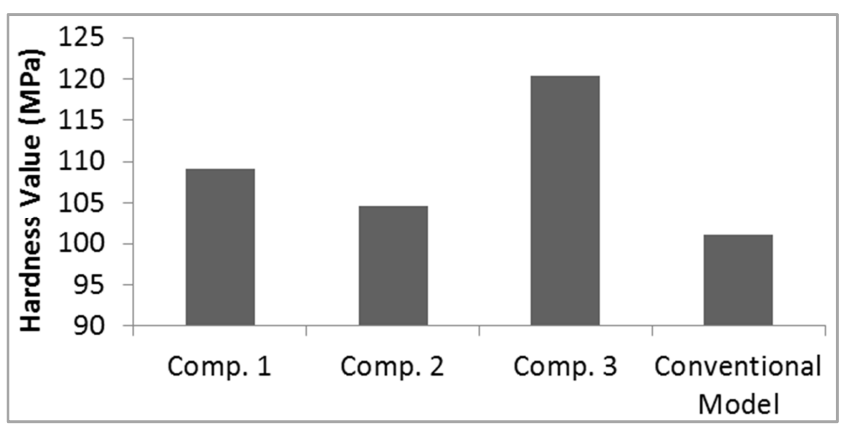

Figure 15. Comparative analysis of specimen hardness value.

From Figure 15 above, it was established that hardness of the material varied non-uniformly as the epoxy resin percentage weight increased in the formulation, i.e. hardness decreased as binder content increased from $50 \mathrm{wt} \%$ to $55 \mathrm{wt} \%$, and later increased as binder amount increased from $55 \mathrm{wt} \%$ to $60 \mathrm{wt} \%$. The hardness value obtained for each specimen compared favourably over the conventional model and other materials from other similar researches. High hardness values were attributed to increase in bonding and close packing that strain hardened the composite brake pad, hence rises in hardness values. The hardness value of conventional brake pad is $101 \mathrm{MPa}$ [18] [20]. While preparing the samples for thermal conductivity test through machining (plane turning and facing) on a lathe machine, it was observed that the HSS tool steel used worn out several times and had to be re-ground. This indicated that the composite specimen is very hard. It was discovered that for all the formulated specimen brake pads, hardness values are above that of the conventional brake pad and those produced from other researches.

\subsection{Tensile Strength Assessment}

Table 10 presents average results of specimen tensile strength after three (3) repeated test runs. While using a pillar drilling machine (RIGI DRILL DP-25) to bore holes through the centre of the abrasive test samples, it was discovered that chips formed (Figure 16) were continuous, showing that the material possesses some measures of ductility. It is shown in Table 10 that decrease in filler content from 31 to $21 \%$ wt resulted in increased tensile strength of the investigated specimen brake pads. Tensile strength of each specimen was compared with that of the conventional pad as shown below in Figure 17. It was discovered that brittleness developed in the composite brake pad as filler content increased in the formulation.

Table 10. Average tensile strength of specimen pads.

\begin{tabular}{lllll}
\hline Materials/Composition & $\begin{array}{l}\text { Average Tensile stress at } \\
\text { break (MPa) }\end{array}$ & $\begin{array}{l}\text { Average Tensile strain } \\
\text { at break (mm/mm) }\end{array}$ & $\begin{array}{l}\text { Average Modulus } \\
\text { (MPa) }\end{array}$ & $\begin{array}{l}\text { Average Load } \\
\text { at break (N) }\end{array}$ \\
\hline Sample Composition 1 & 13.076 & 0.059 & 608.495 & $\begin{array}{l}\text { Average Extension } \\
\text { at break (m) }\end{array}$ \\
Sample Composition 2 & 14.339 & 0.065 & 649.974 & 0.005 \\
Sample Composition 3 & 16.882 & 0.073 & 720.131 & 946.380 \\
\hline
\end{tabular}

The graph illustrating load $(\mathrm{N})$ at break to the extension at break relationship is as shown in Figures 18. On the load/extension graph, each point represents a unique composition of the specimen. Its behaviour as seen from the plots shows that for each test specimen, there was a significant effect on the tensile load required to produce a specific 
extension before rupture. This can be used to measure the specimen's plasticity tendency under tensile loading. The deviation of tensile strength of each composite specimen (comp. 1, 2 and 3) from that of the conventional model is $85.86 \%, \quad 104.86 \%$ and $141.14 \%$ respectively, i.e. the specimens have much higher tensile strength than the conventional model. Tensile strength of the conventional brake pad is $6.80 \mathrm{MPa}$ [20] [30]. The results also compare better than those produced from other similar researches [2] [11] [16] [19] [20].

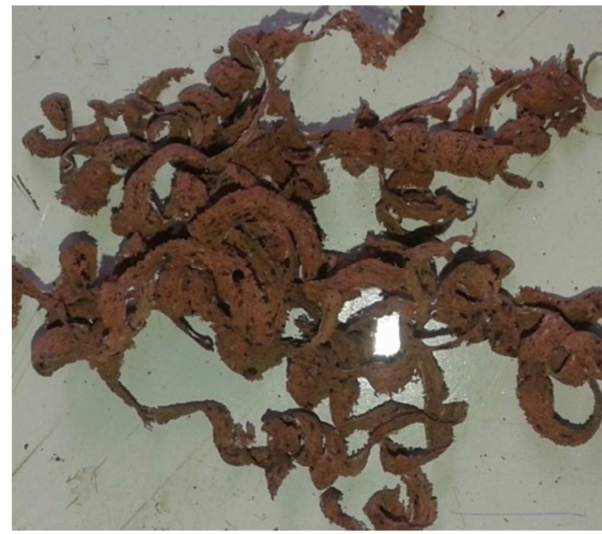

Figure 16. Chips generated from samples during machining.

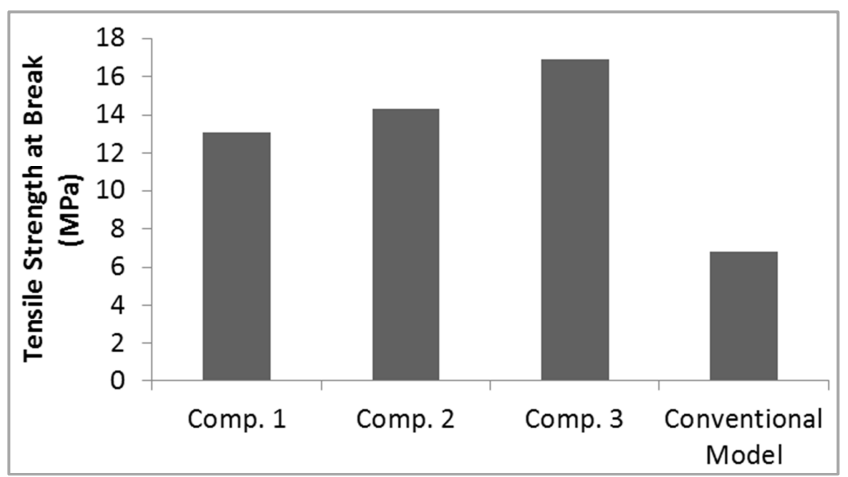

Figure 17. Comparative analysis of tensile strength of specimen pads.

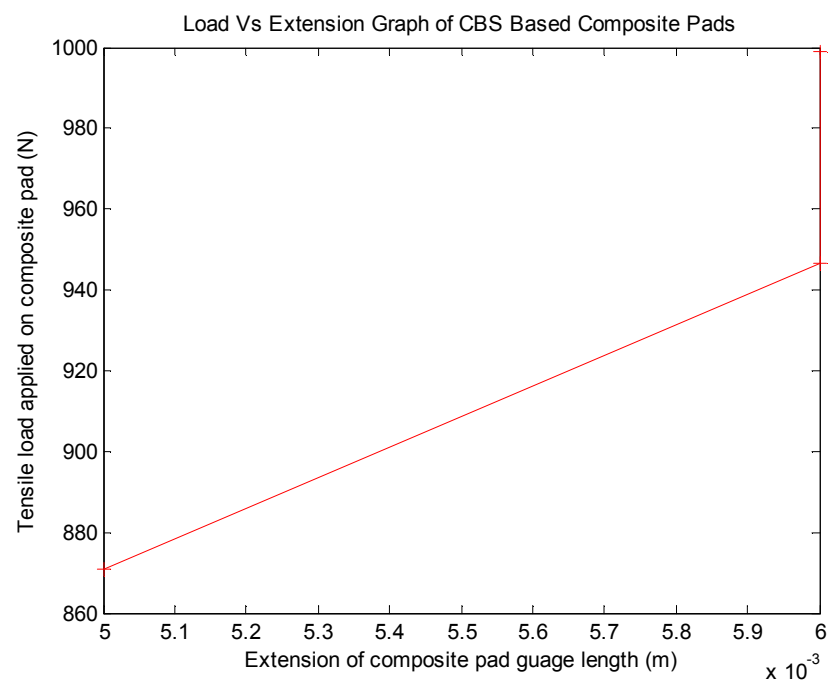

Figure 18. Load VS Extension graph of the specimen.

\subsection{Compressive Strength Assessment}

Compressive strength of each specimen pad is presented in Table 11. As shown in the table, the bracketed negative signs preceding both compressive strength and load at break values show that none of the specimen broke under the influence of the applied load. The universal testing machine that was used could not compress it further, thus, the values are those recorded at the time the tester could not compress further. This means that the specimens require very high compressive load before rupture. Recorded compressive strength values of composite specimens were compared with each other based on composition as illustrated in Figure 19.

Table 11. Compressive strength of specimen pads.

\begin{tabular}{lllll}
\hline $\begin{array}{l}\text { Materials / } \\
\text { Composition }\end{array}$ & $\begin{array}{l}\text { Compressive } \\
\text { Stress (MPa) }\end{array}$ & $\begin{array}{l}\text { Strain at break } \\
(\mathbf{m m} / \mathbf{m m})\end{array}$ & $\begin{array}{l}\text { Modulus } \\
\text { (MPa) }\end{array}$ & $\begin{array}{l}\text { Load at } \\
\text { break (N) }\end{array}$ \\
\hline $\begin{array}{l}\text { Sample } \\
\text { Composition 1 }\end{array}$ & $(-) 15.133$ & 0.032 & 472.912 & $(-) 596.912$ \\
$\begin{array}{l}\text { Sample } \\
\text { Composition 2 }\end{array}$ & $(-) 18.970$ & 0.037 & 511.326 & $(-) 643.672$ \\
$\begin{array}{l}\text { Sample } \\
\text { Composition 3 }\end{array}$ & $(-)) 23.150$ & 0.040 & 583.114 & $(-) 705.824$ \\
\hline
\end{tabular}

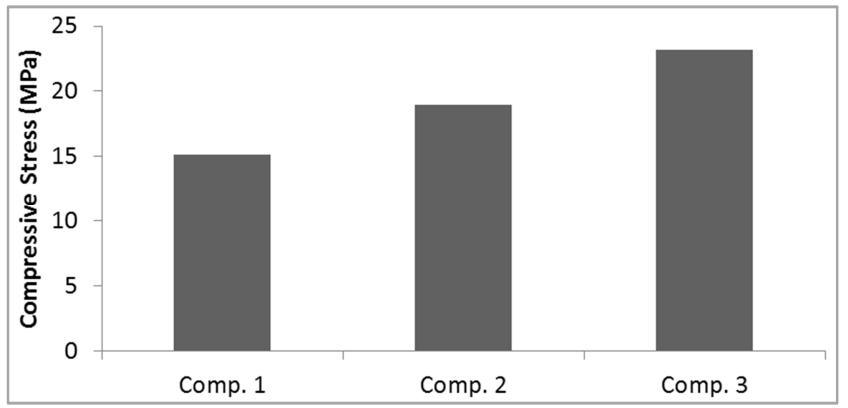

Figure 19. Analysis of specimen compressive strength.

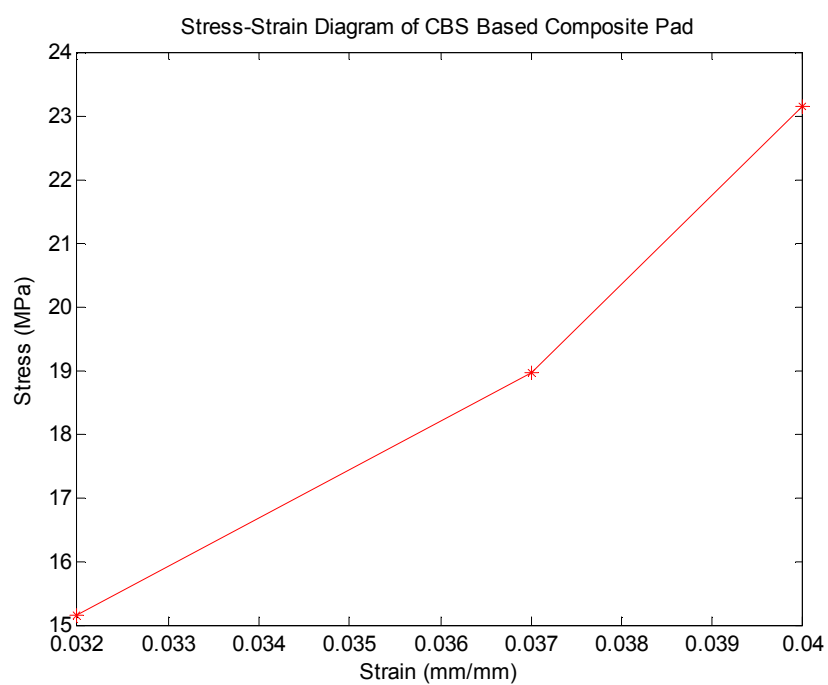

Figure 20. Stress-Strain analyses of the specimens.

Figure 19 shows the compressive strengths of the formulated brake pad samples. The results followed the same trend as that of hardness values. The compressive strength increased with an increase in the $\mathrm{wt} \%$ of epoxy resin content 
which is due to fair dispersion of the filler particles with the binder resulting in fair filler particle to binder interaction. The fair particle dispersion improved the particle to binder interaction and consequently increased the ability of the specimen pad to restrain gross deformation [19] [20]. Figure 20 presents the stress-strain analysis of the composite specimen.

From Figure 20, it was observed that there is a successive increase in stress-strain values as the filler content decreased in the composite formulation. Specimen having $60 \% \mathrm{wt}$ of binder has the highest compressive strength with corresponding highest stress-strain value. This can be attributed to an increase in pore packaging capability of the filler particles with the matrix. The decrease in compressive strength as the $\mathrm{wt} \%$ of epoxy resin decreased was due to the interference of particles in the mobility or deformability of the matrix. This interference was created through the physical interaction and immobilization of the binder by the presence of mechanical restraints, thereby reducing the strength [19] [20].

Result findings as compared with conventional brake pad and others existing agro-waste based brake pads obtained from similar researches are summarized in Table 12.

Table 12. Summary of results compared with the existing asbestos-free brake pads.

\begin{tabular}{|c|c|c|c|c|c|c|}
\hline Properties & $\begin{array}{l}\text { Commercial brake } \\
\text { pad (asbestos } \\
\text { based) }\end{array}$ & $\begin{array}{l}\text { Laboratory } \\
\text { formulation (Palm } \\
\text { kernel shell) }\end{array}$ & $\begin{array}{l}\text { Laboratory } \\
\text { formulation } \\
\text { (Bagasse) }\end{array}$ & $\begin{array}{l}\text { Laboratory } \\
\text { formulation (ES } \\
\text { particles at } \\
18 w t \% \text { of GA) }\end{array}$ & $\begin{array}{l}\text { Laboratory } \\
\text { formulation } \\
\text { (Periwinkle shell } \\
\text { at } 125 \mu \mathrm{m} \text { ) }\end{array}$ & $\begin{array}{l}\text { Laboratory } \\
\text { formulation } \\
(\mathrm{CBS} \text { at } 300 \mu \mathrm{m})\end{array}$ \\
\hline Specific gravity $\left(\mathrm{g} / \mathrm{cm}^{3}\right)$ & 1.890 & 1.650 & 1.430 & 1.650 & 1.010 & 1.010 \\
\hline Wear rate $(\mathrm{mg} / \mathrm{m})$ & 3.800 & 4.400 & 4.200 & 4.000 & - & 3.934 \\
\hline Friction Coefficient & $0.30-0.40$ & 0.44 & 0.42 & 0.30 & $0.35-0.41$ & $0.32-0.35$ \\
\hline Thickness swell in water (\%) & 0.9 & 5.03 & 3.48 & 3.21 & 0.39 & 1.19 \\
\hline Hardness Values (MPa) & 101.0 & 92.0 & 100.5 & 99.1 & 116.7 & 120.3 \\
\hline Compressive strength (MPa) & 110.0 & 103.5 & 105.6 & 103.0 & 147.0 & $23.2+$ \\
\hline Tensile strength (MPa) & 7.00 & 6.80 & - & - & - & 16.88 \\
\hline Thermal conductivity $(\mathrm{W} / \mathrm{mK})$ & 0.539 & 1.460 & - & - & - & $0.239-0.338$ \\
\hline
\end{tabular}

\section{Summary and Conclusions}

CBS was used as filler to produce CBS based composite brake pad. The newly developed automotive brake pad was investigated by determining its physical, mechanical and tribological properties. Based on properties like density, water absorption, oil absorption, abrasion resistance, coefficient of friction, thermal conductivity, hardness, tensile strength, and compressive strength, the results obtained for the agro-waste based brake pads compared favourably with that of commercial brake pad and other existing ones. Specimen labeled as comp. 3 in particular gave superior performance over others.

The density, water absorption, oil absorption, abrasion resistance, coefficient of friction, thermal conductivity, hardness, tensile strength, and compressive strength, of the most effective composite specimen (comp. 3), are $1.010 \mathrm{~g} / \mathrm{cm}^{3}$, $1.188 \%, \quad 0.275 \%, \quad 3.934 \times 10 \mathrm{E}-6, \quad 0.32, \quad 0.2387 \mathrm{~W} / \mathrm{mk}$, 120.33MPa, 16.882MPa, and 23.150MPa, respectively. From investigation, the results of this work indicated that CBS which is an agro-waste material can be effectively used as a replacement for asbestos in friction lining/ brake pad materials.

Unlike asbestos based brake pad, the composite brake pad developed in this work is eco-friendly without any known health implication. This is adjudged based on information obtained from literature review of the agro-waste [20] [21] [22].

\section{Acknowledgements}

Authors of this work acknowledge Dr. Oladele of Metallurgy and Materials Engineering department, and $\mathrm{Mr}$. Bello of Physics department (both are staff of Federal
University of Technology, Akure - FUTA), for their contribution to the success of this work in terms of influencing access to the School laboratory where specimen production and some analysis were carried out.

\section{References}

[1] Anon (2004). Automotive Brake Repairs Trends and Safety Issues. Retrieved from http//www.sirim.my/amtee/pm/brake.hltm

[2] Aigbodion, V. S., Akadike, U., Hassan, S. B., Asuke, F., Agunsoye, J. O. (2010). Development of Asbestos - free Brake Pad Using Bagasse. Tribology in industry, 32 (1), 45-50.

[3] Bono, S. G., Dekyrger, W. J. (1990). Auto Technology, Theory and Service ( ${ }^{\text {nd }}$ ed.). DELMAR Publishers, New York, 45-48.

[4] Aigbodion, V. S., Agunsoye, J. O. (2010). Bagasse (Sugarcane waste): Non-Asbestos Free Brake Pad Materials. LAP Lambert Academic Publishing, Germany, ISBN 978-3-8433-8194-9.

[5] Dagwa, I. M., Ibhadode, A. O. A. (2006). Determination of Optimum Manufacturing Conditions for Asbestos-free Brake Pad Using Taguchi Method. Nigerian Journal of Engineering Research and Development. Basade Publishing Press Ondo, Nigeria, 5(4), pp. 1-8.

[6] Sivarao, M., Amarnath, M. S., Rizal, A. K. (2009). An investigation toward development of economical brake lining wear alert system, IJENS, Vol: 9, No. 9, pp. 251-256.

[7] Deepika, K., Bhaskar, Reddy C., Ramana, Reddy D. (2013). Fabrication and Performance Evaluation of a Composite Material for Wear Resistance Application. International Journal of Engineering Science and Innovative Technology (IJESIT) Volume 2, Issue 6, pp. 1-6. 
[8] Publication of the International Ban Asbestos Secretariat (2013). Australia. Retrieved fromhttp://www.commerce.wa.gov.au/worksafe/content/safety _topics/Asbestos/Ban_on_chrysotile_asbestos.html

[9] Blau, J. P. (2001). Compositions, Functions and Testing of Friction Brake Materials and their Additives. Being a report by Oak Ridge National Laboratory for U.S. Dept. of Energy. Retrieved from http://www.Ornl.gov/-webworks/cppr/y2001/rpt/112956.pdf, 78-80.

[10] Kim, S. J., Kim, K. S., Jang, H. (2003). Optimization of manufacturing parameters for brake lining using taguchi method. Journal of Material Processing Technology, 136, pp. 202-208.

[11] Dagwa, I. M., Ibhadode, A. O. A. (2005). Design and Manufacture of Automobile Disk Brake Pad Test Rig. Nigerian Journal of Engineering Research and Development, Vol. 4, No. 3, pp. 15-24.

[12] Dagwa, I. M. (2005). Development of Automobile Disk Brake Pad from Local Materials, Ph.D. (Manufacturing Engineering) Thesis, University of Benin, Benin City, Nigeria.

[13] Mathur, R. B., Thiyagarajan, P., Dhami, T. L. (2004). Controlling the Hardness and Tribological Behavior of Non-asbestos Brake Lining Materials for Automobiles. Journal of Carbon Science, 5 (1), pp. 6-11.

[14] Bashar, Dan-Asabe, Peter, Madakson B., Joseph, Manji (2012). Material Selection and Production of a Cold-worked Composite Brake Pad. World Journal of Engineering and Pure and Applied Science (WJEPAS). 2(3), pp. 96.

[15] Ishidi, E. Y., Kolawole, E. G., Sunmonu, K. O. (2011). Morphology and thermal property of alkaline treated palm kernel nut shell HDPE composite. Journal of Emerging Trends in Engineering and Applied Sciences (JETEAS), 2(2), pp.346-350

[16] Yawas, D. S., Aku, S. Y., Amaren, S. G. (2013). Morphology and properties of periwinkle shell asbestos-free brake pad. Journal of King Saud University - Engineering Sciences.

[17] Aderiye Jide (2014). Kaolin Mineral Material for Automobile Ceramic Brake Pad Manufacturing Industry. International Journal of Technology Enhancements and Emerging Engineering Research, Vol. 2, Issue 3, pp. 84-88.

[18] Idris, U. D., Aigbodion, V. S., Abubakar, I. J., Nwoye, C. I. (2013). Eco-friendly asbestos free brake-pad: Using banana peels. Journal of King Saud University - Engineering Sciences

[19] Edokpia, R. O., Aigbodion, V. S., Obiorah, O. B., Atuanya, C. U. (2014). Evaluation of the Properties of Ecofriendly Brake
Pad Using Egg Shell Particles-Gum Arabic. ScienceDirect, Elsevier. B. V. DOI: 10.1016/j.rinp.2014.06.003

[20] Ademoh A. Nuhu, Adeyemi I. Olabisi. (2015). Development and Evaluation of Maize Husks (Asbestos-Free) Based Brake Pad. International Institute for Science, Technology and Education (IISTE): Industrial Engineering Letters -IEL. Vol. 5, No. 2, pp. 67-80.

[21] Olupona, J. A., Abodunwa, J. A., Fayoyin, F. K. (2003). Response of laying hens to graded levels of cocoa bean shells. In: Proceedings of the 28th Ann. Conf., Nig. Soc. Anim. Prod. (NSAP), Volume 28, pp. 247-249

[22] Joseph, A. B. (2012). Enhancement of the Nutritive value of Cocoa (theobroma cacao) Bean Shells for use as Feed for Animals through a two- stage Solid State Fermentation with pleurotus ostreatus and aspergillus niger. Kumasi College of Science, Department of Biochemistry and Biotechnology, Kwame Nkrumah University of Science and Technology.

[23] Nicholson, G. (1995). Facts about Friction, P \& W Price Entreprises, Inc., Croydon, PA. Retrieved from $\mathrm{http} / / / w w w . g o o g l e . c o m . n g /$ search?q=facts+about+friction

[24] Cease, H., Derwent, P. F., Diehl, H. T., Fast, J., Finley, D. (2006). Measurement of mechanical properties of three epoxy adhesives at cryogenic temperatures for $\mathrm{CCD}$ construction: Fermi National Accelerator Laboratory. Batavia IL 60510.

[25] Simpson Strong-Tie (2014): flexiblized Epoxy Adhesive. FX-523

[26] Hooton, N. A. (1969). Metal-Ceramic Composites in High-Energy Friction Applications (Concerning aircraft brakes). Bendix Technical Journal, Spring 1969, pp. 55-61

[27] Friction Coefficient Experiment (2005). Retrieved from http:// www.pstcc.edu/departments/natural_behavioral_sciences/Web \%20Physics/Experiment\%2005.htm (2005).

[28] Oluyamo, S. S., Bello, O. R., and Yomade, O. J. (2012). Thermal Conductivity of Three Different Wood Products of Combretaceae Family; Terminalia superb, Terminalia ivorensis and Quisqualis indica. Journal of Natural Sciences Research. Vol. 2, No. 9, pp. 18-29

[29] Khurmi, R. S. and Gupta, J. K. (2004). A Text Book of Workshop Technology (Manufacturing Processes). S. Chand \& Company Ltd. Reprinted edition. Pp. 58-67

[30] Ibhadode, A. O. A., Dagwa, I. M. (2008). Development of asbestos-free friction lining material from palm kernel shell. Journal of the Brazilian Society of Mechanical Sciences and Engineering. J. Braz. Soc. Mech. Sci. \& Eng. Vol.30 (2). Rio de Janeiro. ISSN 1678-5878. 